\title{
ОРИГИНАЛНО И НАВРЕМЕННО ЛЕКСИКОГРАФСКО ИЗДАНИЕ
}

\author{
Petar SOTIROV \\ Uniwersytet Marii Curie-Skłodowskiej w Lublinie
}

Елена Крейчова, Надежда Сталянова, Олга Сорока. Кратък тематичен речник на българския, чешкия, полския и украинския език. София: Парадигма, 2016, 156 стр.

Създаването на двуезични и особено на многоезични тематични речници не е често явление в славянската лексикографска практика. Затова публикуването на Кратък тематичен речник на българския, чешкия, полския и украинския език с авторки Е. Крейчова, Н. Сталянова и О. Сорока заслужава похвала и пропагандиране на постижението. Това издание запълва една сериозна празнина в славистичната лексикографска практика, която едва в последните години беше отчасти компенсирана с издаването на няколко двуезични тематични речници, засягащи българския, словашкия, украинския и чешкия език. Предлаганото издание включва паралелен материал от четири славянски езика, което му придава особена оригиналност, постигната благодарение на положените усилия от страна на авторския колектив, съставен от утвърдени имена от областта на лексикографията и на методиката на преподаването на чужд език.

Според авторките целта на тематичния речник е да подпомага процеса на обучението по чужд език на студентите слависти, но прегледът на съдържанието показва, че постигнатото далеч надхвърля предварително определеното предназначение. Основание за това твърдение е фактът, че включеният в речника езиков материал от 21 тематични области, който е представен в много прегледен вид, представлява изключително удобна база за многостранни съпоставителни научни изследвания. Така например сравняването на езиковите изрази в отделните езици дава потвърждение за общата им славянска принадлежност, като същевременно показва 
и някои национални специфики, например при заемането от чужди езици или в областта на езиковите представи на отделните народи. Във връзка с това може да се забележи по-осезателното присъствие на гръцка и ориентална лексика в българския език, на немски заемки в полския език, асиметрия при роднинските названия между различните езици и пр.

От гледна точка на методиката на чуждоезиковото обучение съдържанието на речника не поражда никакви възражения. Включените в него тематични групи са определени въз основа на лексикалния материал на учебници по български език като чужд, които предвиждат постигането на равнище А1 - B1 от европейската езикова рамка. По този начин в обсега на внимание са се оказали следните тематични групи: Дом, Семейство, Време (астрономическо и метеорологччно), Свободно време и забавления, Работа, Образование и просвета, Човешко тяло и здраве, Храни и хранене, Градът и селото, Комуникация, Търговия и услуги, Транспорт и пътуване, Изкуство и култура, Държава и общество, Икономика, Вяра и религия, Земята, Растения, Животни, Околна среда и екология, Вселената. При представянето на езиковия материал за изходен е приет българският език, затова най-напред са подадени българските думи и изрази, а след това последователно са посочени техните съответствия в чешкия, полския и украинския език. В някои от случаите са посочени и примери за употреба. Преводните еквиваленти са съвсем точни, при това похвално е старанието на авторките да се съобразят с етнокултурните специфики при търсенето на подходящото преводно съответствие.

Изработването на Кратък тематичен речник на българския, чешкия, полския и украинския език с автори Е. Крейчова, Н. Сталянова и О. Сорока и неговото публикуване от издателство Парадигма е едно полезно, оригинално, навременно и затова особено похвално начинение, което заслужава да бъде посочено като пример и с това да се насърчи подготвянето на бъдещи подобни издания. Предложеното издание притежава всички черти на сериозен лексикографски труд и полезно дидактично помагало и затова със сигурност ще намери положителен отзвук сред широк кръг потребители - не само сред предподавателите и изучаващите славянски език като чужд, но и сред специалистите лексикографи, изследователите от областта на славянското съпоставително езикознание, както и сред всички любители на хуманитарните занимания. 